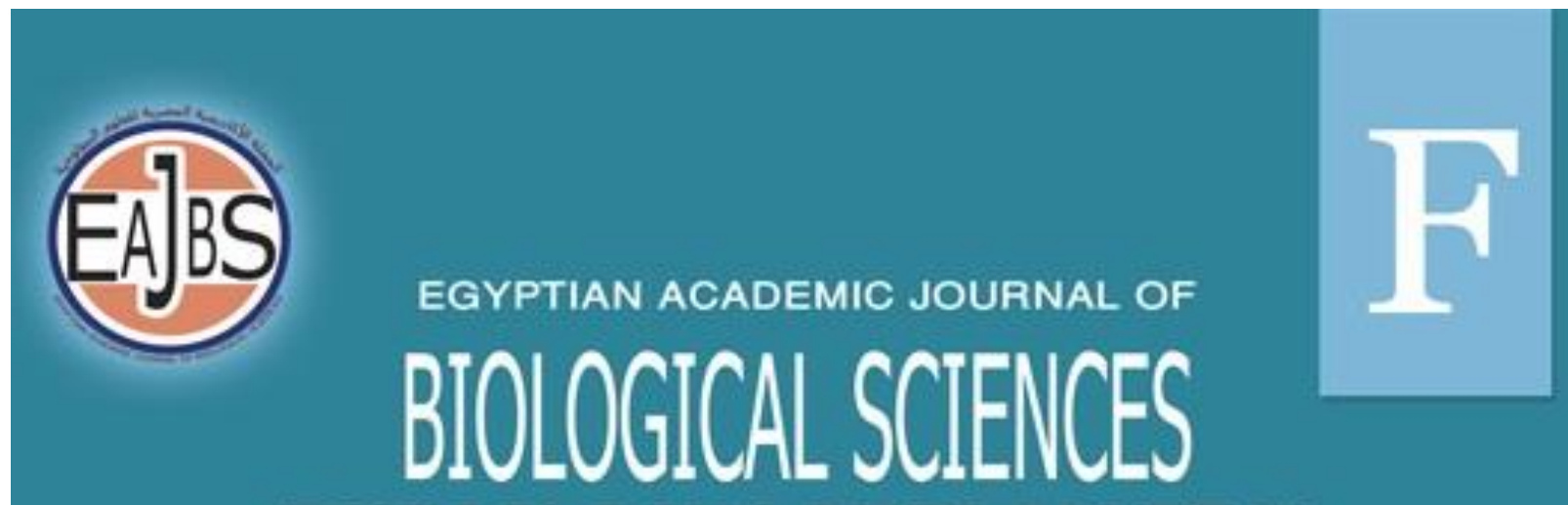

TOXICOLOGY \& PEST CONTROL

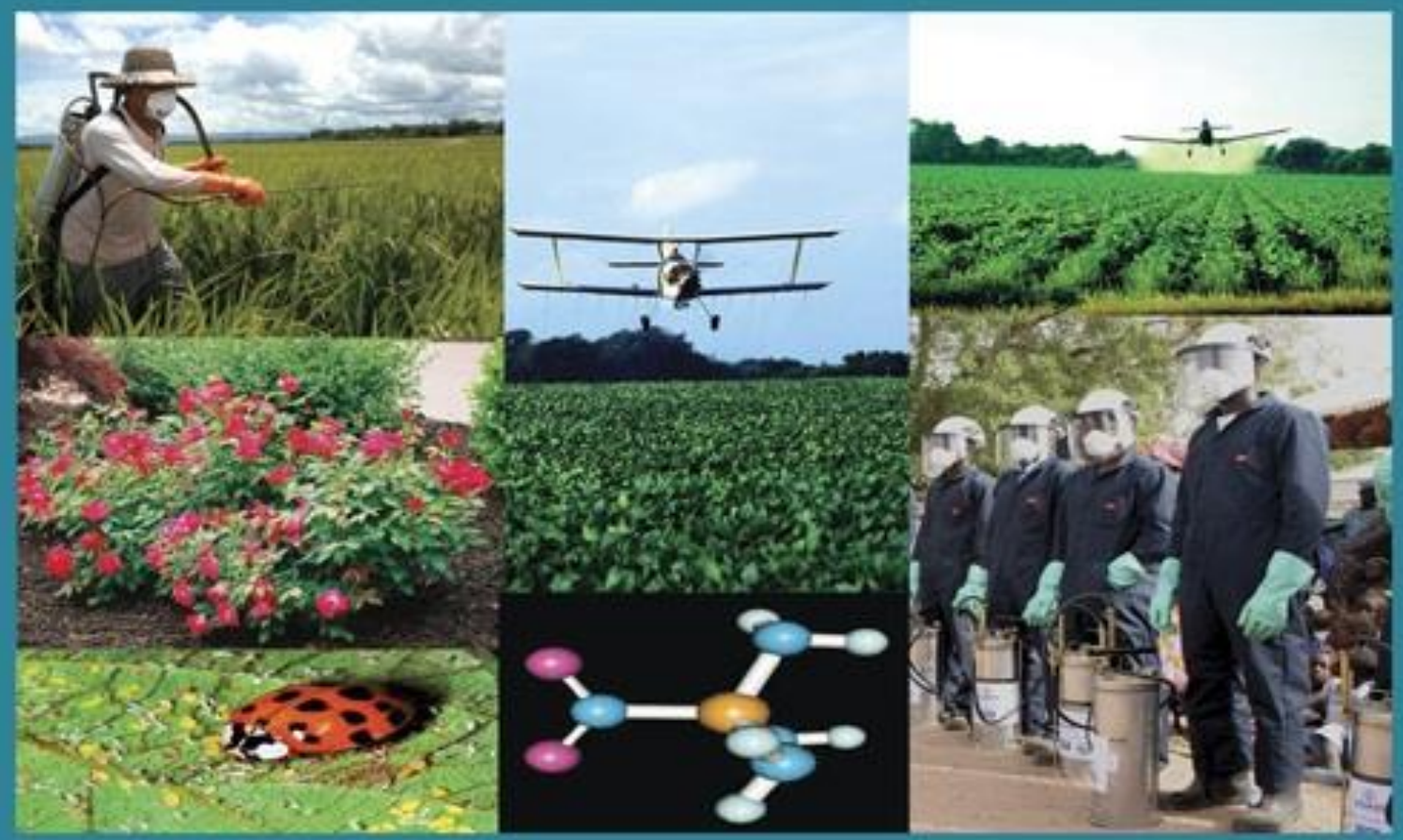

ISSN

2090-0791

WWW.EAJBS.EG.NET

Vol. 13 No. 1 (2021)

$\underline{\text { www.eajbs.eg.net }}$

Citation: Egypt. Acad. J. Biolog. Sci. (F.Toxicology \& Pest control) Vol.13(1)pp237-245(2021)

DOI: 10.21608/EAJBSF.2021.165005 
Egypt. Acad. J. Biolog. Sci., 13(1):237- 245 (2021)

Egyptian Academic Journal of Biological Sciences

F. Toxicology \& Pest Control

ISSN: 2090 - 0791

http://eajbsf.journals.ekb.eg/

\section{Biological Control of Cowpea aphid, Aphis craccivora Koch infesting Squash Plants by Releasing Predator, Coccinella septempunctata under Glasshouse Conditions}

Elsherbeni, M. K. G. and Emam, A. S.

Plant Protection Research Institute, A.R.C., Dokki, Giza, Egypt

E-Mail: merfat kasem@yahoo.com

\section{ARTICLE INFO}

Article History

Received: 21/1/2021

Accepted: 29/3/2021

\section{Keywords:}

Biological control, Aphis craccivora, Cucurbita pepo L., Coccinella septempunctata $\mathrm{L}$.

\section{ABSTRACT}

This study was carried out to evaluate the management of Cowpea aphid, Aphis craccivora Koch (Homoptera: Aphididae) which infesting squash plants, Cucurbita pepo L. by releasing three levels of the seven spotted lady beetle, Coccinella septempunctata L. (Coleoptera: Coccinellidae) (40, 80, 120 eggs/plant). This study was carried out at two locations (Governorates), Perkash (Giza Governorate) and Tokh (Qaliobya Governorate) during successive season 2020 under glasshouse conditions.

At Giza Governorate, in the first level of release (40 eggs/plant), the reduction percentages in the population of A. craccivora increased gradually whereas they were $21.9,31.9,40.6,46.5$ and $55.4 \%$ on midFebruary, first-March, mid-March, first-April and mid-April respectively. Also, in the second level of release ( 80 eggs/plant), the reduction percentages in the population increased gradually whereas they were 25.5 , $35.5,43.2,50.9$ and $58.0 \%$ on the same dates respectively. Lastly, in the third level of release (120 eggs/plant), the reduction percentages in the population increased gradually whereas they were $28.3,38.8,46.1,52.1$ and $63.7 \%$ on the same dates, respectively. The same trend was achieved at Qaliobya Governorate.

\section{INTRODUCTION}

Squash (Cucurbita pepo L.) fruits are considered one of the most important vegetable crops in Egypt and all over the world which are cultivated in the open field and under greenhouses conditions. Also, its cultivated area increased gradually during the last years, especially in the newly reclaimed areas for purposes of local consumption and exportation to the foreign markets. It contains some nutritional compounds for human feeding such as a moderate quantity of mineral salts, it is eaten cocked as an immature fruit which is rich with fibers and vitamins or consumed for the mature seed which is a good source of fats and protein (Abdein 2016).

Squash plants infested with a large scale of different insects such as Cowpea aphid, Aphis craccivora Koch (Homoptera: Aphididae) which consider one of the most damaging insects infesting squash plants and other vegetables crops either in the open field or under greenhouses conditions whereas it causes numerous damage in both quantity and quality for the crop directly by plant juice to loosen or indirectly by plant disease-transmitting (Abd ElSalam et al., 1982; Masaki et al., 1991 and Ibrahim 2005). 
The seven spotted lady beetle, Coccinella septempunctata L. (Coleoptera: Coccinellidae) is the commonest lady beetle known in Egypt, it is an important predator of many aphid species; eggs and small nymphs of mealybugs, jassids, eggs and larvae of cotton leafworm (Bilashini et al. 2017). The adults and small stages are often encountered in large numbers on the plants infested with aphids. They feed on these harmful insects and often play a great role in suppressing them under control. Both the adult and larval stages feed on insects harmful to plants, such as aphids and scale insects (Anonymous 1997). Adults can be killing up to 100 aphids per day (Arnett et al. 2015). The seven spotted lady beetle, $C$. septempunctata lives in a wide variety of habitats, any place where there are plants and aphids may attract these species (Fleming 2000). The lady beetle kills its prey outright and then devours it (Waldbauer 2007). Under field conditions, numerous coccinellids consume nectar, honeydew, pollen, fruit, vegetation, and fungus. These non-prey foods are used by coccinellids to increase survival when prey is scarce, reduce mortality during diapause, fuel migration, and enhance reproductive capacity. Each of these non-prey foods has unique nutritional and defensive characteristics that influence its suitability for lady beetles (Lundgren 2015).

This study was carried out to evaluate the management of Cowpea aphid, $A$. craccivora which infesting squash plants (C. pepo) by releasing three levels of the seven spotted lady beetle, $C$. septempunctata.

\section{MATERIALS AND METHODS}

This study was carried out to evaluate the management of Cowpea aphid, Aphis craccivora Koch (Homoptera: Aphididae) which infesting squash plants, Cucurbita pepo L. by releasing three levels of the seven spotted lady beetle, Coccinella septempunctata L. (Coleoptera: Coccinellidae) (40, 80, 120 eggs/plant). This study was carried out at two locations (Governorates), Perkash (Giza Governorate) and Tokh (Qaliobya Governorate) during successive season 2020 under glasshouse conditions.

\section{Release of $C$. septempunctata:}

Releasing was conducted on squash plants grown at the two locations, Perkash (Giza Governorate) and Tokh (Qaliobya Governorate) during successive season 2020 under glasshouse conditions. Both at the two places, glasshouse divided into three replects $(5 \times 8 \mathrm{~m}$ for each) for squash plants which were sown beginning of January month 2020. Each replect for each release level and each replect also divided into six plots three plots for that release level and the other three plots used as control. The normal release and recommended agricultural practices were applied, also no chemical control against aphid was used during the whole experimental period.

Naturally, the numbers of $C$. septempunctata stages were recorded. Therefore, three levels of $C$. septempunctata eggs; the first level consists of 40 eggs (one card), the second level consists of 80 eggs (two cards) and the third one consists of 120 eggs (three cards) were released to encouragement the normal predator population to reduce the aphid. C. septempunctata were released (one time) by the beginning of February on squash plants at both two locations in 2020 season.

Samples were randomly taken bi-weekly at both two locations and counting started from the beginning of February in squash plants. Ten new plants were examined from each plot (three leaves for each plant), were made by a hand lens for counting the alive insects and the predator and took the mean numbers. Both surfaces of the leaf were inspected for the presence of aphid (Mangoud 2000). 


\section{Statistical Analysis:}

The obtained results were statistically analysed and the percent reduction of $A$. craccivora after $C$. septempunctata was released was calculated according to Henderson and Tilton equation (1955).

The data were subjected to analysis of variance (ANOVA) and the means were compared by L.S.D. test at 0.05 level, using SAS program (SAS Institute 1988).

\section{RESULTS AND DISCUSSION}

\section{Giza Governorate:}

Three levels of Coccinella septempunctata L. eggs; first level (40 eggs on one card), second level ( 80 eggs on two cards) and the third level (120 eggs on three cards) were released (one time) at the beginning of February on squash plants during 2020 season.

\section{First Level of Release (40 eggs/plant):}

Results in Table (1) and Fig. (1) indicated that the number of A. craccivora in the $1^{\text {st }}$ release plot decreased gradually from 49 on the $1^{\text {st }}$ February to 40, 29, 20, 12 and 5 individuals/plant, in mid-February, first-March, mid-March, first-April and mid-April, respectively as compared to control which aphid populations changed from 45 individuals/plant, on first-February to $47,50,58,65$ and 70 individuals/plant, at the same dates, respectively. The present results showed that the percent reduction of A craccivora in the $1^{\text {st }}$ release plot increased gradually to reach $21.9,31.9,40.6,46.5$ and $55.4 \%$ at the same dates respectively.

Table 1: Population fluctuations of A. craccivora in the $1^{\text {st }}$ plot release at level (40eggs) of C. septempunctata at Giza Governorate.

\begin{tabular}{|l|c|c|c|}
\hline \multicolumn{1}{|c|}{ Date } & Release plot & Chick plot (Control) & \% Reduction \\
\hline First February & 49 & 45 & - \\
\hline Mid February & 40 & 47 & 21.9 \\
\hline First March & 29 & 50 & 31.9 \\
\hline Mid-March & 20 & 58 & 40.6 \\
\hline First April & 12 & 65 & 46.5 \\
\hline Mid April & 5 & 70 & 55.4 \\
\hline F (0.05) & \multicolumn{3}{|c|}{} \\
\hline L.S. D & \multicolumn{3}{|c|}{} \\
\hline
\end{tabular}

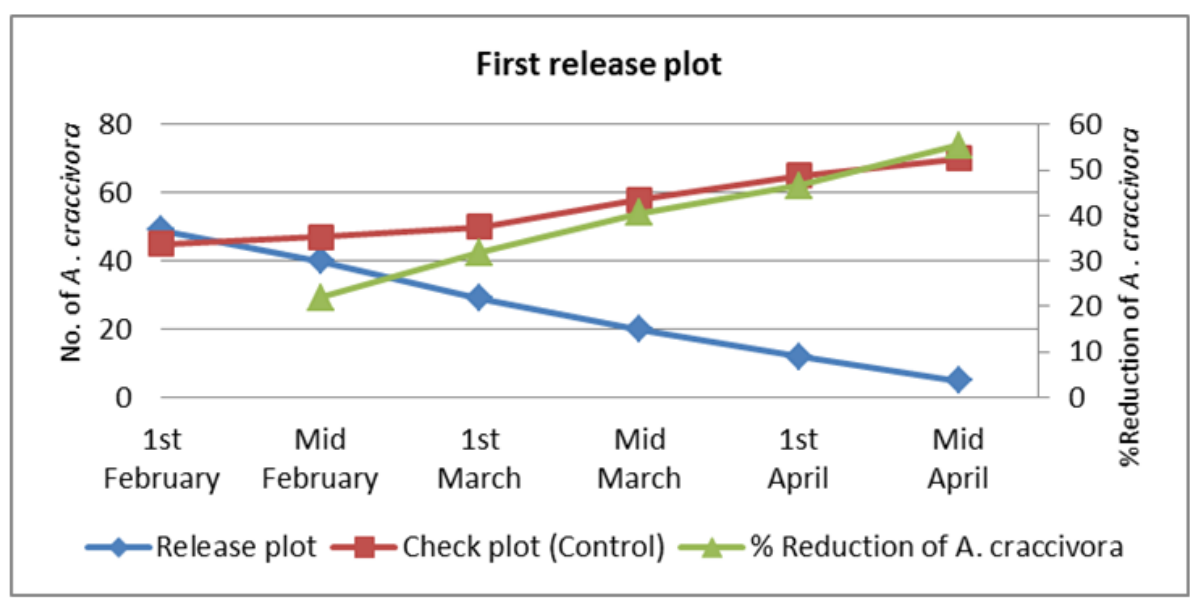

Fig.1: Population fluctuations of A. craccivora in the $1^{\text {st }}$ plot release at level (40eggs) of C. septempunctata at Giza Governorate. 


\section{Second Level of Release (80 eggs/plant):}

Results in Table (2) and Fig. (2) indicated that the number of A. craccivora in the $2^{\text {nd }}$ release plot decreased gradually from 52 on the $1^{\text {st }}$ February to $42,31,20,11$ and 5 individuals/plant on mid-February, first-March, mid-March, first-April and mid-April, respectively as compared to control which aphid populations changed from 48 individuals/plant, on first-February to $52,59,67,75$ and 82 individuals/plant, at the same dates, respectively. The obtained results showed that the percent reduction of A. craccivora in the $2^{\text {nd }}$ release plot increased gradually to reach $25.5,35.5,43.2,50.9$ and $58.0 \%$ at the same dates respectively.

Table 2: Population fluctuations of A. craccivora in the $2^{\text {nd }}$ plot release at level (80eggs) of C. septempunctata at Giza Governorate.

\begin{tabular}{|l|c|c|c|}
\hline \multicolumn{1}{|c|}{ Date } & Release plot & Chick plot (Control) & \% Reduction \\
\hline First February & 52 & 48 & - \\
\hline Mid February & 42 & 52 & 25.5 \\
\hline First March & 31 & 59 & 35.5 \\
\hline Mid-March & 20 & 67 & 43.2 \\
\hline First April & 11 & 75 & 50.9 \\
\hline Mid April & 5 & 82 & 58.0 \\
\hline F (0.05) & \multicolumn{3}{|c|}{} \\
\hline L.S.D & $\mathbf{2 3 3 . 4 3}$ \\
\hline
\end{tabular}

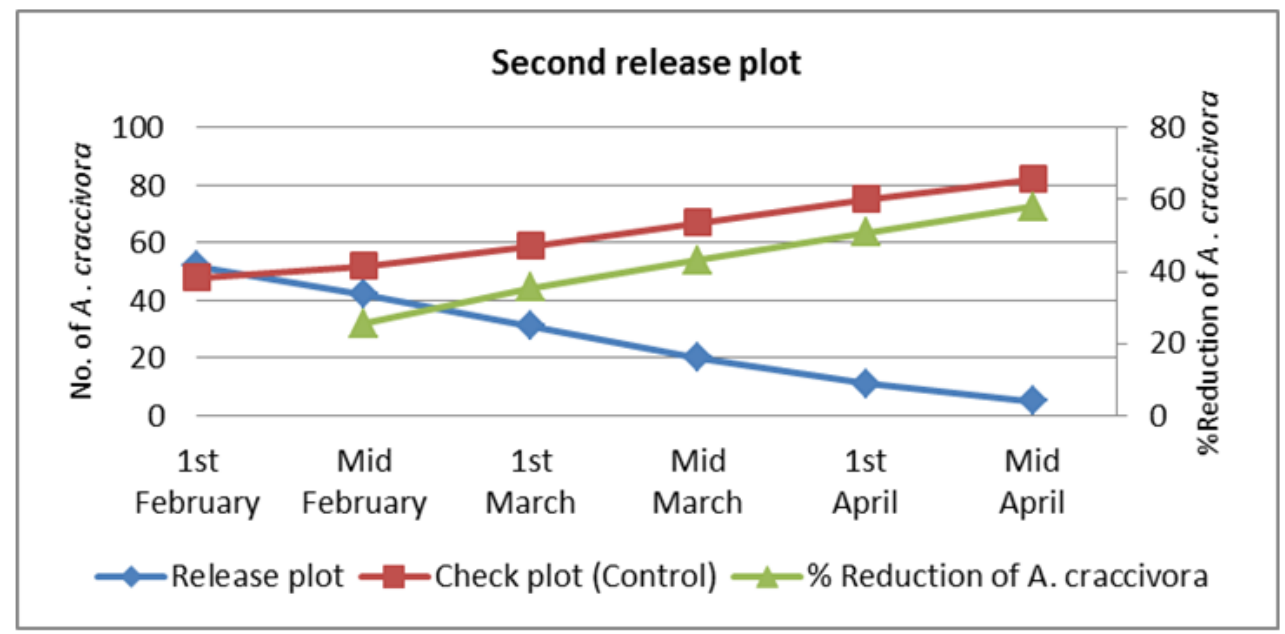

Fig.2: Population fluctuations of A. craccivora in the $2^{\text {nd }}$ plot release at level (80eggs) of $C$. septempunctata at Giza Governorate.

\section{Third Level of Release (120 eggs/plant):}

Results in Table (3) and Fig. (3) indicated that the number of A. craccivora in the $3^{\text {rd }}$ release plot decreased gradually from 55 on the $1^{\text {st }}$ February to $45,30,18,10$ and 4 individuals/plant, in mid-February, first-March, mid-March, first-April and mid-April, respectively as compared to control which aphid populations changed from 50 individuals/plant, on first-February to $57,62,69,80$ and 88 individuals/plant, at the same dates, respectively. The results showed that the percent reduction of $A$. craccivora in the $3^{\text {rd }}$ release plot increased gradually to reach $28.3,38.8,46.1,52.1$ and $63.7 \%$ at the same dates respectively. 
Table 3: Population fluctuations of $A$. craccivora in the $3^{\text {rd }}$ plot release at level (120eggs) of C. septempunctata at Giza Governorate.

\begin{tabular}{|l|c|c|c|}
\hline \multicolumn{1}{|c|}{ Date } & Release plot & Chick plot (Control) & \% Reduction \\
\hline First February & 55 & 50 & - \\
\hline Mid February & 45 & 57 & 28.3 \\
\hline First March & 30 & 62 & 38.8 \\
\hline Mid-March & 18 & 69 & 46.1 \\
\hline First April & 10 & 80 & 52.1 \\
\hline Mid April & 4 & 88 & 63.7 \\
\hline F (0.05) & \multicolumn{3}{|c|}{} \\
\hline L.S.D & $\mathbf{2 1 2 . 3 3}$ \\
\hline
\end{tabular}

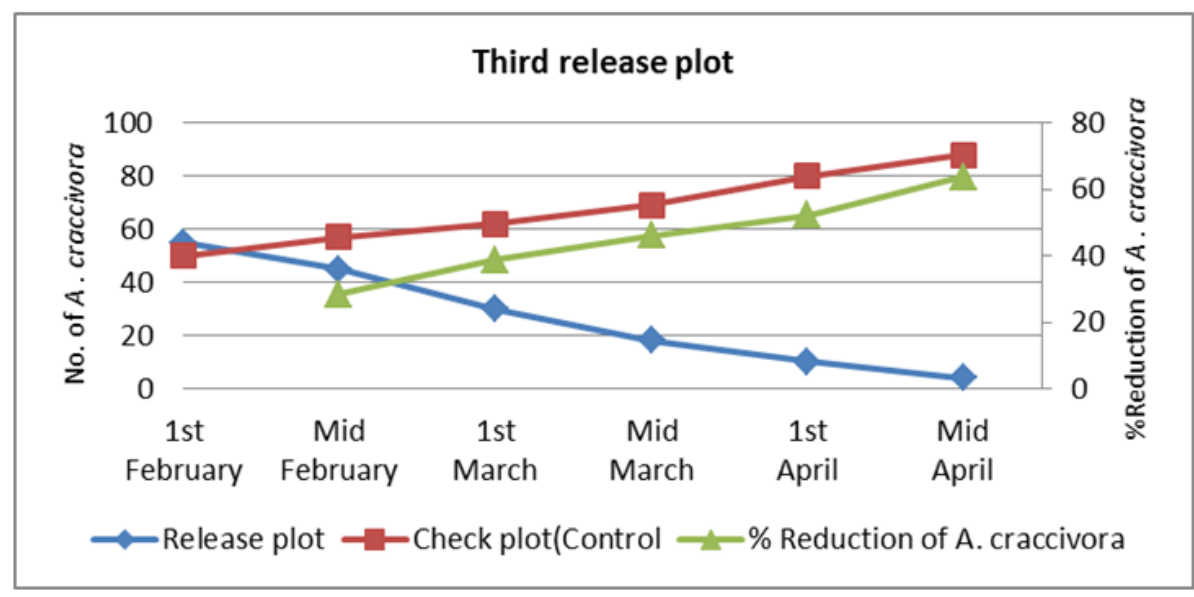

Fig.3: Population fluctuations of A. craccivora in the $3^{\text {rd }}$ plot release at level (120eggs) of C. septempunctata at Giza Governorate.

\section{At Qaliobya Governorate:}

First Level of Release (40 eggs/plant):

Results in Table (4) and Fig. (4) indicated that the number of $A$. craccivora in the $1^{\text {st }}$ release plot decreased gradually from 50 on the $1^{\text {st }}$ February to $45,32,20,11$ and 5 individuals/plant, on mid-February, first-March, mid-March, first-April and mid-April, respectively as compared to control which aphid populations changed from 47 individuals/plant, on first-February to 55, 60, 67, 72 and 75 individuals/plant, at the same dates, respectively. In addition, the results showed that the percent reduction of A. craccivora in the $1^{\text {st }}$ release plot increased gradually to reach $23.1,34.9,44.1,48.9$ and $56.4 \%$ at the same dates respectively.

Table 4: Population fluctuations of A. craccivora in the $1^{\text {st }}$ plot release at level (40eggs) of C. septempunctata at Qaliobya Governorate

\begin{tabular}{|l|c|c|c|}
\hline \multicolumn{1}{|c|}{ Date } & Release plot & Chick plot (Control) & \% Reduction \\
\hline First February & 50 & 47 & - \\
\hline Mid February & 45 & 55 & 23.1 \\
\hline First March & 32 & 60 & 34.9 \\
\hline Mid-March & 20 & 67 & 44.1 \\
\hline First April & 11 & 72 & 48.9 \\
\hline Mid April & 5 & 75 & 56.4 \\
\hline F (0.05) & \multicolumn{4}{|c|}{} \\
\hline L.S.D & $\mathbf{2 5 1 . 7 1}$ \\
\hline
\end{tabular}




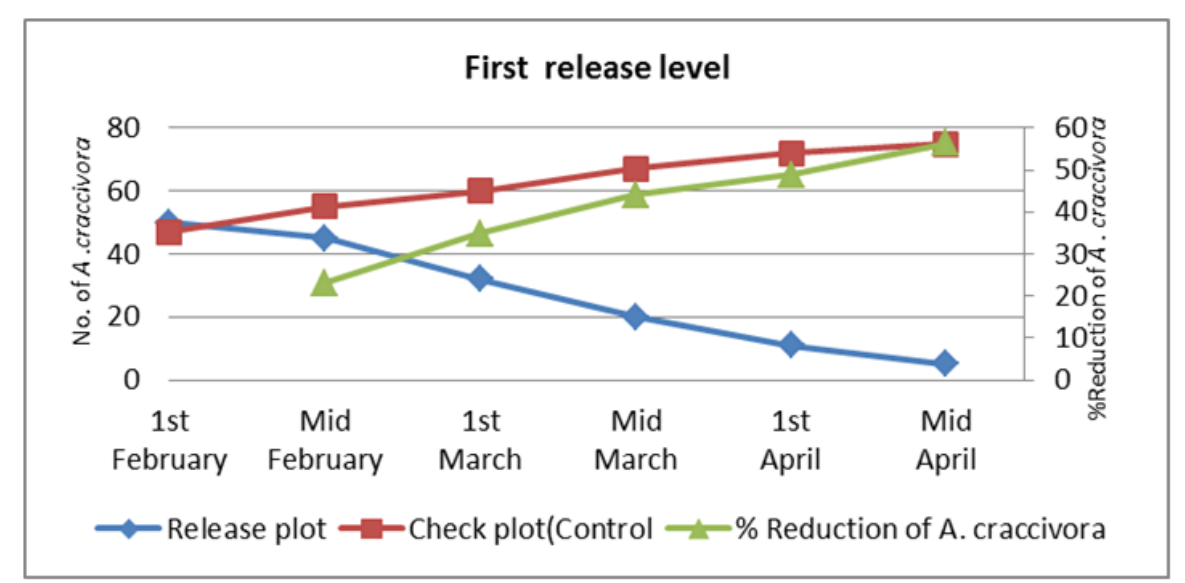

Fig.4: Population fluctuations of A.craccivora in the $1^{\text {st }}$ plot release at level (40eggs) of $C$. septempunctata at Qaliobya Governorate.

\section{Second Level of Release (80 eggs/plant):}

Results in Table (5) and Fig. (5) indicated that the number of A. craccivora in the $2^{\text {nd }}$ release plot decreased gradually from 52 on the $1^{\text {st }}$ February to $42,30,19,10$ and 4 individuals/plant, in mid-February, first-March, mid-March, first-April and mid-April, respectively as compared to control which aphid populations changed from 48 individuals/plant, on first-February to $53,60,68,75$ and 80 individuals/plant, at the same dates, respectively. In addition, the results showed that the percent reduction of $A$. craccivora in the $2^{\text {nd }}$ release plot increased gradually to reach $26.9,37.0,44.2,52.3$ and $62.5 \%$ at the same dates respectively.

Table 5: Population fluctuations of A. craccivora in the $2^{\text {nd }}$ plot release at level (80eggs) of C. septempunctata at Qaliobya Governorate.

\begin{tabular}{|l|c|c|c|}
\hline \multicolumn{1}{|c|}{ Date } & Release plot & Chick plot (Control) & \% Reduction \\
\hline First February & 52 & 48 & - \\
\hline Mid February & 42 & 53 & 26.9 \\
\hline First March & 30 & 60 & 37.0 \\
\hline Mid-March & 19 & 68 & 44.2 \\
\hline First April & 10 & 75 & 52.3 \\
\hline Mid April & 4 & 80 & 62.5 \\
\hline F (0.05) & \multicolumn{3}{|c|}{} \\
\hline L.S.D & $\mathbf{2 7 7 . 3 1}$ \\
\hline
\end{tabular}

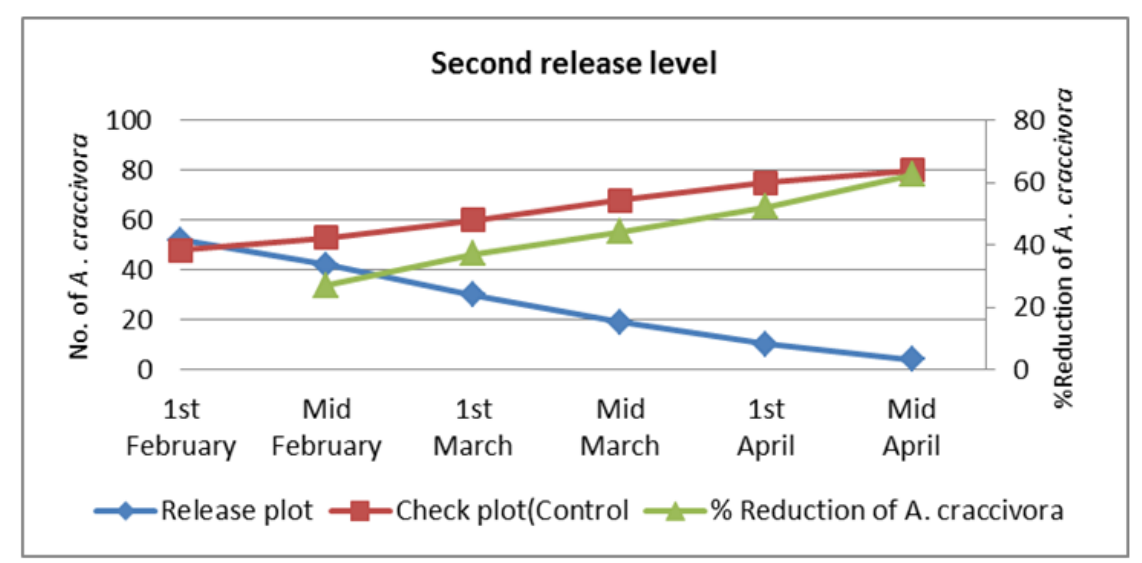

Fig.5: Population fluctuations of A.craccivora in the $2^{\text {nd }}$ plot release at level (80eggs) of $C$. septempunctata at Qaliobya Governorate. 


\section{Third Level of Release (120 eggs/plant):}

Results in Table (6) and Fig. (6) indicated that the number of $A$. craccivora in the $3^{\text {rd }}$ release plot decreased gradually from 53 on the $1^{\text {st }}$ February to 44, 30, 18, 9 and 3 individuals/plant, in mid-February, first-March, mid-March, first-April and mid-April, respectively as compared to control which aphid populations changed from 49 individuals/plant, on first-February to $58,68,79,85$ and 90 individuals/plant, at the same dates, respectively. In addition, the results showed that the percent reduction of A. craccivora in the $3^{\text {rd }}$ release plot increased gradually to reach $29.9,40.1,48.4,53.6$ and $68.6 \%$ at the same dates, respectively.

Table 6: Population fluctuations of $A$. craccivora in the $3^{\text {rd }}$ plot release at level (120eggs) of C. septempunctata at Qaliobya Governorate.

\begin{tabular}{|l|c|c|c|}
\hline \multicolumn{1}{|c|}{ Date } & Release plot & Chick plot (Control) & \% Reduction \\
\hline First February & 53 & 49 & - \\
\hline Mid February & 44 & 58 & 29.9 \\
\hline First March & 30 & 68 & 40.1 \\
\hline Mid-March & 18 & 79 & 48.4 \\
\hline First April & 9 & 85 & 53.6 \\
\hline Mid April & 3 & 90 & 68.6 \\
\hline F (0.05) & \multicolumn{3}{|c|}{} \\
\hline L.S.D & $\mathbf{2 8 8 . 9 3}$ \\
\hline
\end{tabular}

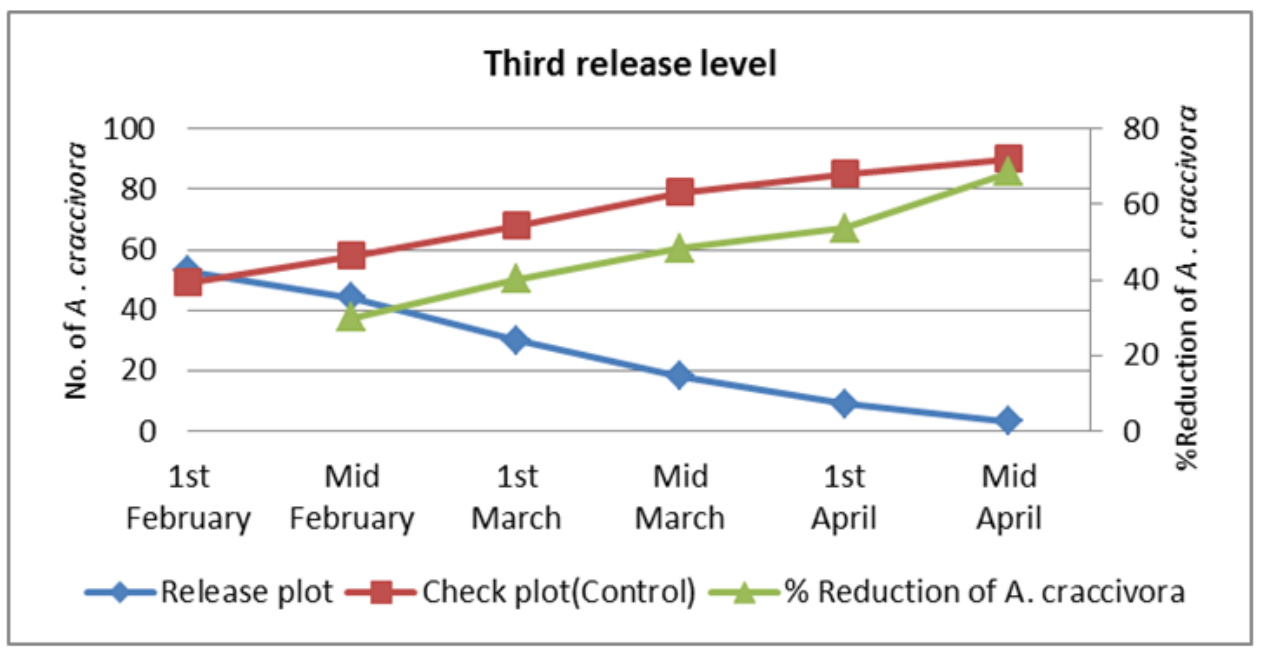

Fig.6: Population fluctuations of A. craccivora in the $3^{\text {rd }}$ plot release at level (120eggs) of C. septempunctata at Qaliobya Governorate.

Statistical analysis showed that were highly significant differences between the three releasing levels (40, 80 and 120 eggs/plant) of $C$. septempunctata predator in reduction of $A$. craccivora at both the two locations compared to control.

These results obtained are in agreement with those obtained by Mangoud (2009) who found that the seven spotted lady beetle, C. septempunctata is an important predator of aphids play a good role in reducing the population density of the woolly apple aphid, Eriosoma lanigerum (Homoptera: Aphididae) attacking apple trees. Also, these results are in agreement with those obtained by Mangoud (2003) who stated that the seven spotted lady beetle, $C$. septempunctata is an important predator of aphids play a good role in reducing the population density of the green peach aphid, Myzus persicae and the cotton aphid, A. gossypii (Homoptera: Aphididae) attacking apple trees. 
Also, these results are in harmony with those obtained by Hoyt and Madsen (2005) found that the control of aphid species complex is complicated by the continued dispersal of aphids from the roots to the aerial portions of the tree, and a corresponding dispersal in the opposite direction. Release $C$. septempunctata adopted here can cope very well with this behaviour. Brar and Kanwar (2005) in field experiments in India found C. septempunctata was an effective predator against $A$. craccivora infesting fenugreek germplasm. El-Aish $e t$ al. (2004) stated that the role of the predator C. septempunctata in biological suppressing of cereal aphids showed that the eggs last 2-3 days and the 1st, 2nd, 3rd and 4th larval instars have lasted 3,2, 2 and 4 days, respectively, the pupal stage lasted 8 days at the room temperature. The adult predator consumed 46.13 aphids, while the larval consumed 26.9 aphids daily. Fang et al. (2012) found the coccinellids, C. septempunctata good controlling $B$. brassicae in cotton fields at yellow Rever valley in China.

\section{REFERENCES}

Abdein, M.A.E. (2016). Squash plants between classic and modern genetics. MOJ Proteomics Bioinform, 3(1): 14-17.

Abdel- Salam, A. L.; Metwally, A. M.; Yousef, A. A.; El- Boghdady, N. A. and Hegab, M. F. (1982). Mites associated with vegetable plants in Egypt. Proc. $1^{\text {st }}$ Conference of Plant Protection Research Institute, 3: 61 - 79.

Anonymous (1997). Ladybird Beetle. Microsoft Encarta 97 Encyclopedia. Houghton Mifflin Company.

Arnett, J.; Ross, N. M. and Jaques, H. E. (2015). How to know the beetles. W. C. Brown Company Publishers, 35(2): 31-39.

Bilashini, Y.; Singh, T. K. and Singh, R. K. (2017). Biological control potential of Coccinella septempunctata Linnaeus (Coleoptera: Coccinellidae) on major Homopteran pests of rapeseed. Journal of Biological Control, 2 (21): 157-162.

Brar, K. S. and Kanwar, J. S. (2005). Management of Aphis craccivora infesting fenugreek germplasm. Punjab-Vegetable-Grower, 31(2): 41-44.

El-Aish, H. S.; El-Ghariani, I. M. and Al-Mabruk, A. H. (2004). Survey of cereal aphids and their natural enemies and effect of the predator $C$. septemunctata on biological suppression of cereal aphids in Al-Jabal Al-Akhdar Region, Libya. Proceeding of $1^{\text {st }}$ Arab Conference or Applied Biological Pest Control. Egyptian Journal of Biological Pest Control, 14(1): 285-290.

Fang, C. Y.; Wen, S. G.; Cul, S. Z. and Wang, Y. H. (2012). The role of natural enemies in the integrated control of insect pests on cotton. China Cotton 2(3): 42-45.

Fleming, R. C. (2000). Entomology Notes 6 Lady Beetles. http://insects.ummz.lsa. umich. edu/MES/notes/entnotes6.html.

Hendrson, C. F. and Tilton, E. W. (1955). Test with acaricides against the brown wheat mite. Journal of Applied Entomology, 48: 157-161.

Hoyt, S. C. and Madsen, H. F. (2005). Dispersal behavior of the first instar nymphs of the woolly apple aphid. Hilgardia, 30 (2): 267-297.

Ibrahim, M.M.S. (2005). Studies on some integrated control practices for the two- spotted spider mite, Tetranychus urticae Koch on cantaloupe crop. Ph. D. thesis. Faculty of Agricultural Science; Suez Canal University, 110 pp.

Lundgren, J. G. (2015). Relationships of natural enemies and non-prey foods. Springer International, Dordrecht, The Netherlands, 3(2): 34-45.

Mangoud, A. A. H. (2000). Integrated pest management of apple trees. Ph. D. Thesis, Faculty of Agricultur Cairo University Cairo, Egypt, 225pp. 
Mangoud, A. A. H. (2003). Research worker working on mass rearing of predators during working in the Project 604 "Mass rearing of parasites and predators attacking mealybugs and whiteflies".

Mangoud, A. A. H. (2009). Manipulation of the seven spotted lady beetle, C. septempunctata for controlling the wooly apple aphid, Eriosoma lanigerum . Egypt, Journal of Agricultural Research, 85(2): 441-451.

Masaki, M.; Hayase, T. and Miyajin, S. (1991). Notes on eight species of spider mites and predacious thrips intercepted on squash imported from USA, Mexico, Colombia and New Zealand. Research Bulleten of the Plant Pro. Serv., Japan, 27(3): 107114.

SAS Institute 1988. SAS/STAT User`s Guide, Ver. 6.03. SAS Institute Inc., Cary, North Carolina.

Waldbauer, G. (2007). The Birder's Bug Book. Harvard University Press, Cambridge, Massachusetts, 5(4): 365-369.

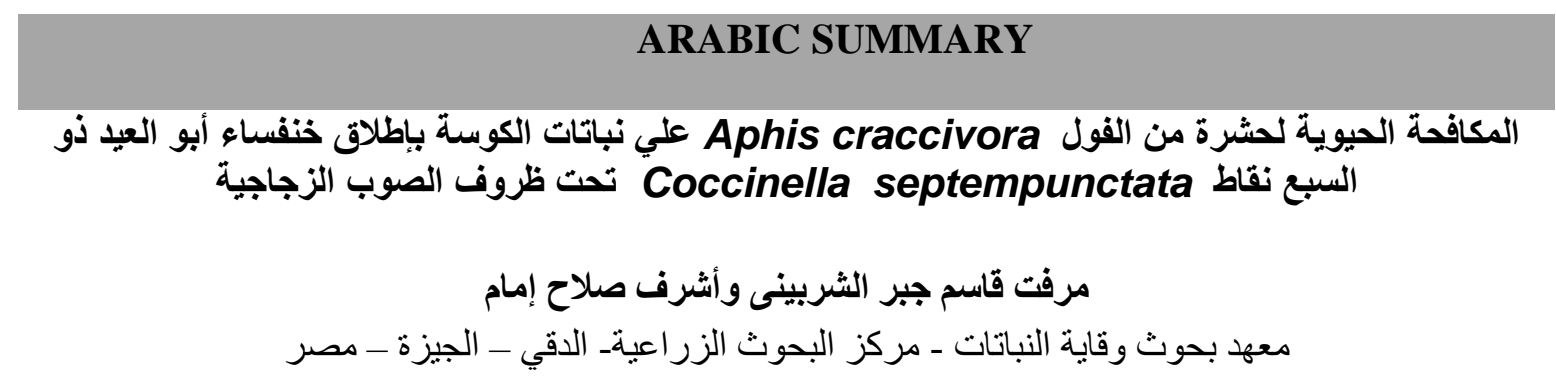

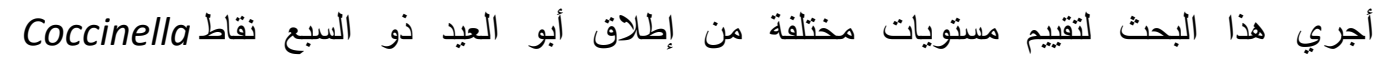
septempunctata L.

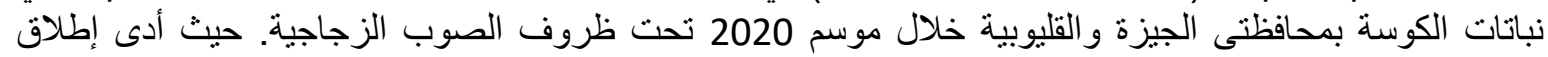

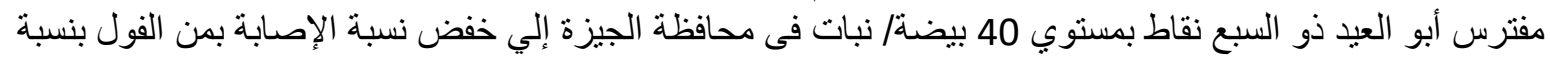

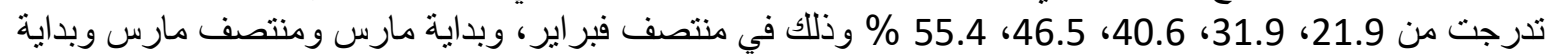

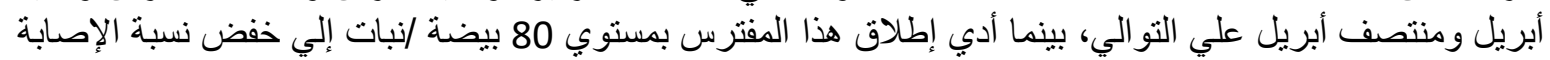

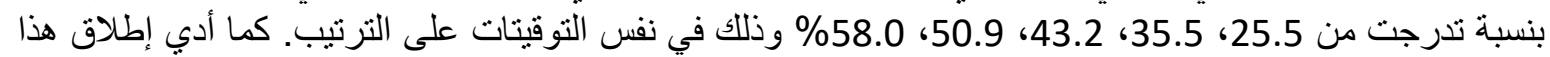

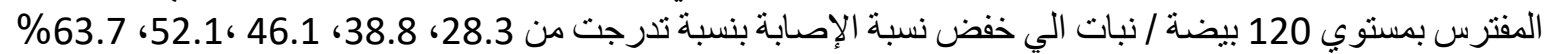

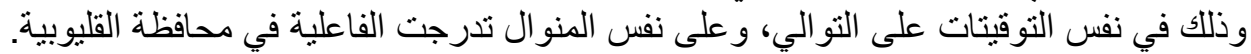

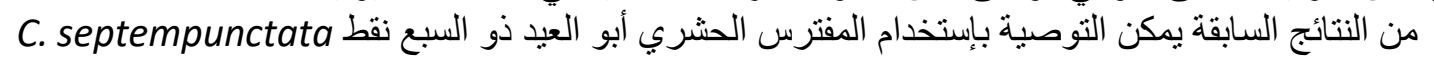

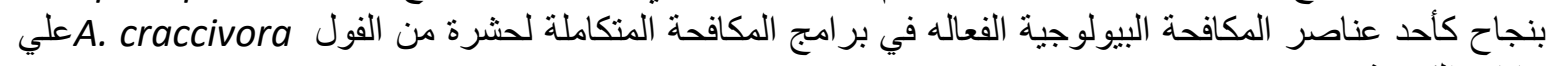
نباتات الكوسة . 